\title{
A Supermarket Acquisition Case: Daring's Market
}

Joseph Larkin, Saint Joseph's University, USA

\begin{abstract}
This case chronicles the growth of a family-owned retail food store business across three generations. Stange's, Inc. is now managed by the grandsons of the founder, John Stange, Sr. Recently, the opportunity arose to purchase Daring's Market, a well-established local grocery store. Students will assume the role of business valuation consultants and prepare pro-forma financial statements for management. This business valuation engagement will utilize several approaches to determine an appropriate asking price, including a free cash flow model and an earnings-based estimate approach.
\end{abstract}

Keywords: Business Valuation; Pro-forma Financial Statements; Free Cash Flow

\section{CASE OVERVIEW}

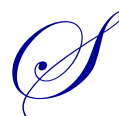

tange, Inc. is a privately held corporation which owns and operates a convenience store and a small supermarket in Scranton, Pennsylvania. Corporate leadership would like to grow the business. Recently, a supermarket in nearby Dallas, Pennsylvania, was put up for sale. The management of Stange, Inc. is very much interested in purchasing the business as this acquisition would expand operations significantly.

Daring's Market is a well-established, recently remodeled 16,200 square foot market specializing in meats. Operating for many years, Daring's manufactures many of its own meat products. It is well-known for its kielbasa, sausage, bologna, hot dogs, smoked hams and bacon. These products are much sought after by the local customer base. Ray Daring, the current owner, wishes to sell the business and retire. Stange, Inc. is considering a purchase offer to Mr. Daring in the amount of $\$ 850,000$ for the business, equipment and inventory. It is agreed that Daring will retain ownership of the building and lease it to Stange, Inc. The lease payment is calculated at $\$ 1 / \mathrm{ft} . / \mathrm{month}$. Daring's fiscal year ends on March 31. Feeling uncomfortable about the fact that Daring's has shown a 9-month loss of about $\$ 11,000$ for 2012 (see Exhibit 1), Scott C. Stange, president of Stange, Inc., engaged the firm of Burton \& Broome, CPAs, to evaluate the proposed purchase. He would like Burton \& Broome (B\&B) to prepare a pro-forma income statement for Daring's Market.

\section{BACKGROUND}

Stange, Inc. is owned equally by Scott C. Stange, president of the corporation, and John N. Stange, the corporate vice president. The original Stange's Market, located in Scranton, was founded in 1956 by John N. Stange, Sr. He operated it through 1978 at which time he sold it to his son, John N. Stange, Jr.

From an early age, John N. Stange, III, worked in the store along with his father and grandfather before and after school and during the summer months. After graduating high school in 1981, John went to work for his father full-time in the store and in 1984, he enlisted in the U.S. Navy. While in the Navy, John was rated as a ship's serviceman and was responsible for the operation of the ship's retail store. While still in the Navy, but close to discharge, John's father learned of the National School of Meat Cutting in Toledo, Ohio. The school provides training for processing, cutting and retail selling of meat and related products. When discharged from the service, John enrolled in the school and, upon completing his schooling, he returned to Scranton and rejoined his father. Within that same year, they sold the original store and purchased a market in the Providence section of Scranton. That market, known as Star Market, was twice the size of their original store and gave them the opportunity to become more competitive in the marketplace. The Stanges' grew the business to a point ready for expansion. 
In 1999, they purchased Catalano's Market, located at 510 Cedar Avenue, in Scranton. They then moved their operation to this location and this market offered the additional retail space they desired. In the same year, John and his father were joined in the business by Scott Stange, John's younger brother. Scott Stange also entered into the family business at an early age, helping whenever he could. At the age of 15, Scott was given responsibility for the grocery, frozen food, dairy, produce and candy departments. He interrupted his tenure with the company to attend Saint Joseph's University, in Philadelphia, Pennsylvania. Majoring in Food Marketing, he graduated magna cum laude in 1993. Immediately after graduation, he went to work for The Kroger Co., a large Midwest supermarket chain.

Scott spent over six years with Kroger. He was exposed to all facets of retail operations, including hands-on experience in all of the functional departments. He worked his way up the management ladder, from trainee to department manager to assistant store manager to co-manager. By 1997, in just four years, he was promoted to the position of store manager of a 29,000 square foot store averaging sales of $\$ 600,000$ per week.

Scott remained with Kroger until 1999 at which time he returned to Scranton. It was then that Stange's Inc. was formed. The shareholders and officers included John N. Stange, Jr. and his two sons - John, III and Scott.

Within 18 months, the corporation purchased a second location, called Fresh Farms Minit Market, located at 3014 Birney Avenue, also in Scranton. It is located within a 15-minute drive of the Cedar Avenue store. Shortly after the acquisition, the name was changed to Stange's Quick Serve. Scott managed the newly acquired store while his brother managed the Cedar Avenue location. Their father gradually took less of a role in operations, as he was nearing retirement age.

\section{DARING'S MARKET}

The critical difference in the operation of Daring's Market under Mr. Daring's leadership and John and Scott Stange's leadership will be in monitoring and control. Daring's operating statements lack sufficient detail and timeliness of reporting to be an effective management tool. Stange's operating statements break out sales and gross profit results by department, provide a very detailed listing of operating expenses and are prepared every four weeks. By taking the perishable department inventories (meat, produce, deli and bakery) every four weeks, and an overall grocery inventory at least three times per year, the statements provide operating results on a more timely basis. This provides management with the necessary tools to quickly identify a problem in a given department, so that it can be addressed more immediately. Currently, Daring's performs a complete store inventory once a year, with quarterly statements estimating gross profit results based on sales and purchases.

B \&B completed a detailed analysis of Daring's income statement. Department percentages to totals were computed based upon a four-week analysis of sales from register detail tapes. Among Daring's strong points are its meat and deli departments. These departments represent 30 percent of the store's overall sales as compared to a typical supermarket's meat and deli department's volume of 18 to 22 percent. Justification for the higher gross profit projection revolves around three factors:

1. The meat and deli department sales and gross profits are combined in this projection because the majority of the items sold in the deli department are manufactured by the meat department which generates a high gross profit percentage.

2. John will be dedicating about 80 percent of his time to managing the meat and deli operations. With Scott supervising the front end, John has a unique opportunity to dedicate the majority of his time and energy to these two departments, whereas the former owner did not have that opportunity and his time was divided between all of the departments in the entire store.

3. Approximately 45 percent of the sales in these two departments are of in-store manufactured product. This is significant for two reasons:

a. First, profit on in-store manufactured product is two-tiered: 1) the normal profit a manufacturer would make by selling the item to the retailer for resale and 2) the profit the retailer makes when he sells that item to his customer. The combined profit on in-store manufactured produce normally averages 40 to 45 percent as compared to the normal meat gross profit of 25 to 28 percent. 
b. The second item of significance for a store that manufactures at these levels of volume and diversity is that, through proper case management, meat that is losing its bloom and/or not selling fast enough can be converted and used in a manufactured item, while it is still fresh and at a much higher profit percentage than just grinding it up for ground beef. The complete significance of these facts are best illustrated by the results that John Stange has achieved at their existing meat store, keeping in mind that their current in-store manufacturing in terms of quantity of product and number of items is less than half of Daring's. In 2011, John's overall meat and deli gross profit for the year was 33 percent. In 2012, it was 38 percent.

To assist B\&B in their projections, Stange, Inc.'s management estimated the following line-by-line analysis of sales breakdown and gross profit for Daring's Market.

\section{Grocery}

Dry grocery sales are projected at 42.5 percent of total sales compared to Daring's existing results of 46 percent. The decrease is projected based upon the expectation that meat and deli sales will increase overall sales through better promotions and merchandising. A gross profit of 18 percent is projected.

\section{Dairy}

Daring's current percentage to total sales in dairy is 4 percent. The projection of 7.5 percent is based on maintaining a broader variety of products, increased promotion through signage and prominent displays, as well as maintaining proper inventory levels to maximize sales. A gross profit of 28 percent is projected.

\section{Frozen}

Current results in 'frozen' are 4.9 percent to total sales. Through better promotion, merchandising and case inventory management, this number can be increased to 5.5 percent. Gross profit is forecast to be 30 percent.

\section{Health and Beauty Aids/General Merchandise}

Daring's existing results are 1.1 percent to total sales. The projection of 1.5 percent can be achieved through resets to increase the variety of general merchandise (GM) available in the store; use of seasonal GM programs, which Daring's currently does not participate in; and the introduction of a private label line of health and beauty aid products (First Choice). The projected gross profit is 27 percent.

\section{Combined Meat and Deli}

Daring's current percentage to total sales is 30 percent. The projection maintains the same percentage to total sales. Gross profit is projected at 36 percent based on the combined sales/gross of meat and deli, the tremendous gross profit potential on the in-store manufactured product, and the intensified concentration of a fulltime member of management (owner) of this department.

\section{Produce}

Daring's produce percentage to total sales is 7.9 percent. Of all the departments in the store, the produce department is the one department that has the greatest opportunity for improvement in terms of percentage to total and generated gross profit results. Rotation, inventory levels, signage, variety, and conditioning of product is lacking. Building the department's percentage to total sales to 9.5 percent and gross profit level to 35 percent can be accomplished through concentration on the basics of produce merchandising. Currently, the department is neglected. With increased management attention, proper display techniques, rotation, inventory control, and promotion, the department will capture a larger percentage of the customer's grocery dollar and become an important contribution to the store's gross profit results. 


\section{Bakery}

Currently, Daring's sells Old River Road (ORR) baked products. Initial attempts to add some limited instore baked items have been very successful. The projection provides an increase from 3.1 to 3.5 percent to total sales. This can be achieved by better promotion of existing variety of ORR products and better scheduling to provide an increased variety of in-store baked products on a consistent basis. Gross profit is 28 percent based on ORR gross built into the product.

\section{Management Salaries}

Daring's reported office salaries of $\$ 156,860$ for nine months ended December 31, 2012. B\&B's projection is $\$ 119,000$ broken down as follows: John's entire salary of $\$ 69,398$ and 80 percent of Scott's salary of $\$ 70,050$ will be charged to Daring's. The balance of Scott's salary will be charged to Stange's Quick Serve.

\section{Employee Wages}

Currently, at 8.8 percent of sales and projected at 6.5 percent, the reduction is justified as productivity is expected to improve with increased management supervision. Specifically, the store will be manned by at least one management person every hour that it is open, whereas now the store is open 35 percent of the time, but there is no management/owner supervision. In addition, John and Scott are both working managers, which simply - through their combined efforts - will reduce the number of necessary scheduled employee hours. Vacation expense is included in management and employee wages on both Daring's statements and the projection.

\section{Other Information}

Stange further instructed Burton \& Broome to make the following assumptions in order to generate proforma statements for the consolidated operations:

1. Purchase price of $(\$ 450,000)$, plus inventory on closing date, will approximate $\$ 400,000)$.

2. Stange would provide $\$ 80,000$ in cash and borrow $\$ 770,000$ for 15 years at 4 percent interest.

3. The forecast for Daring's Market is for no sales increase from present levels, with an annual increase of 3 percent in operating expenses each year. Stange wanted B\&B to make the conservative estimate for Daring's Market.

4. $\quad$ All other expenses are assumed to have a stable relationship as a percent of sales.

5. Stange provided past financial statements for Daring's Market to B\&B. Daring's Market is for nine months only - as of December 31, 2012 - because their fiscal year ended March 31 (see Exhibits 1-2).

6. Stange estimated that the following expenditures would be necessary to bring Daring's to state-of-the art condition:

a. An annual investment of $\$ 100,000$ in equipment (fixtures, racks, freezers, ovens, etc.) for a period of five years.

b. Annual investment in net working capital of $\$ 50,000$ per year over the same period (inventory investment to prevent stock-outs).

7. The December 31, 2012 Balance Sheet is presented below for reference.

\section{Epilogue}

After several months of successful and profitable operations, an extensive fire destroyed the buildings and its contents. The business was a total loss. The fire was determined to have been caused by an electrical problem in the overhead lighting and was ruled accidental by the authorities. Insurance proceeds were sufficient to cover outstanding obligations and the investment of the owners.

Several months later, the owners purchased a similar market in a nearby town. Unfortunately, due to the keen competition nearby, the corporation dissolved the business and continues to operate only the Britney Avenue Store. 


\section{AUTHOR INFORMATION}

Joseph M. Larkin, Ph.D., is an associate professor of accounting in the Haub School of Business at Saint Joseph's University in Philadelphia, Pennsylvania. He has published in the Journal of Business Case Studies, Journal of Business Ethics, Advances in Management Accounting, The Accounting Educators' Journal and Internal Auditing, as well as several practitioners' journals. Dr. Larkin's teaching interests include Auditing and Managerial Accounting. Prior to entering academe, he worked for a major international public accounting firm in their audit practice. E-mail: jlarkin@ @ju.edu 


\section{EXHIBIT 1}

Daring's

Income Statement

For the 9 months ended December 31, 2012

Sales
Cost of sales
Gross profit
Operating expenses
Employee wages
Office salaries
Payroll taxes
Utilities
Advertising
Insurance
Maintenance
Amortization and depreciation
Other store expenses
Total operating expenses
Net income (loss) from operations
Other (revenue)/expense
Lottery Revenue
Interest expense
Income (loss) before tax
Tax benefit(.25)
Net income (loss) after tax

$\$ 4,724,616$

$\underline{3,713,548}$

$\$ 1,011,068$

Operating expenses

Employee wages

$\$ 418,112$

117,939

49,929

176,957

45,148

28,681

28,898

80,650

$\underline{86,753}$

$\underline{1,033,067}$

$(21,999)$

$(42,362)$

$\underline{35,267}$

$(14,904)$

$\underline{3,726}$

$\underline{(11,178)}$ 


\section{EXHIBIT 2}

\section{Daring's Market \\ Balance Sheet \\ 31-Dec-12}

\section{Assets}

Current Assets

Cash and Equivalents

$\$ 128,137$

Accounts Receivables

56,100

Merchandise Inventory

381,304

Prepaid Taxes

0

Other Assets

$\underline{22,646}$

Total Current Assets

$\underline{588,187}$

Property and Equipment

Building

$\$ 1,844,638$

8,581

Lease hold Improvements

31,740

Furniture and Fixtures

58,854

Automotive Equipment

$\underline{10,050}$

Less: A/D

Net Property and Equipment

Other Assets, Investments

Total Assets

Liabilities and Equity

Current

Accounts Payable

$\$ 124,985$

Mortgage Payable - Current Portion

74,000

Notes Payable

17,824

Taxes Payable

4,016

Other

$\underline{25,382}$

Total

Long-Term Debt

Mortgage Payable

$\$ 353,462$

Notes Payable

$\underline{83,542}$

Total Liabilities

Owners Equity

Common Stock

$\underline{1,953,863}$

$-1,418,958$

$\underline{534,905}$

$\underline{214,485}$

$\underline{\$ 1,337,577}$

Retained Earnings

$\$ 100,000$

$\underline{554,366}$

Total Liabilities and Owner's Equity

437,004

683,211

654,366

$\underline{\$ 1,337,577}$ 


\section{TEACHING NOTES}

\section{Case Overview}

Stange, Inc. is a privately held corporation located in the Scranton/Wilkes-Barre, Pennsylvania area, which owns and operates a small supermarket and a convenience store. This case deals with the potential acquisition of another supermarket - Daring's Market - also located in the Wyoming Valley.

\section{Case Suitability}

This case is best suited for courses such as Mergers and Acquisitions, Cases in Finance, or an Intermediate Financial Management course. It also has limited applicability in certain niche MBA programs.

\section{Case Objectives}

The overall objective is to determine if Stange, Inc. should purchase Daring's Market and, if so, at what price. To achieve the overall objective, several sub-objectives, in sequence, must be met. The following case objectives form the backbone of the analysis:

1. To forecast an annual income statement for Daring's Market

2. To quantify any operating synergies, estimated by John Stange, and to include them in the forecasted income statement

3. To calculate free cash flows for Daring's Market based on the results obtained in Objective \#2

4. To determine Daring's Market value and make a decision to either buy or not buy Daring's Market

\section{Student Questions}

1. Prepare a forecasted annual income statement for Daring's Market for the year ending March 31, 2014, using the nine-month actual as a basis

2. Based on information provided by Stage, discuss any operating synergies that could be realized resulting from the acquisition

3. Using the forecasted income statement from Question 1, prepare a statement of free cash flows for Daring's Market for the year ending March 31, 2014

4. Determine the value of Daring's Market using an earnings-based approach

5. What price would you advise Stange to offer to acquire Daring's? 